\title{
A clinical magnetic resonance imaging study of the traumatised spinal cord more than 20 years following injury
}

\author{
Dajue Wang ${ }^{1}$, R Bodley ${ }^{2}$, P Sett ${ }^{3}$, B Gardner ${ }^{1}$ and H Frankel ${ }^{1}$ \\ ${ }^{1}$ National Spinal Injuries Centre, Stoke Mandeville Hospital, Aylesbury, Buckinghamshire, HP21 8AL, UK, \\ ${ }^{2}$ Department of Radiology, ${ }^{3}$ The Regional Spinal Injuries Centre, Southport District General Hospital, Town Lane, \\ Kew, Southport, Merseyside, PR8 6NJ, UK
}

\begin{abstract}
One hundred and fifty three patients who had sustained a spinal cord injury more than 20 years previously were assessed neurologically and by MRI scanning of their spinal cords. The spinal cord pathologies shown were, in order of prevalence, extended atrophy, malacia, syrinx, cyst, disruption and tethering. There was no relationship between the prevalence of any type of pathology and the degree of spinal canal compromise or angulation of the spine adjacent to the level of injury. Neurological changes after initial neurological stabilisation were seen only in patients with extended atrophy, malacia or a syrinx, not in those with only a cyst or cord disruption. Tethering is always associated with other lesion(s). Longer syrinxes were more likely to have associated neurological changes than shorter ones. The most common neurological change was pain.
\end{abstract}

Keywords: spinal cord injury; magnetic resonance imaging; chronic spinal cord lesions; clinical correlation

\section{Introduction}

Following spinal injury, chronic (secondary and tertiary) changes occur in the spinal cord over many years. These include extended atrophy, malacia, syrinx, cyst, cord disruption and tethering. ${ }^{1-11}$

MRI findings in the spinal cord in the early stages following injury have been widely described. ${ }^{12-19}$ This is the first study of a series of patients injured more than 20 years previously.

Understanding the chronic changes in the spinal cord following injury is important both for assisting good clinical care and for developing research into the environment within which spinal cord regeneration will occur.

\section{Patients and methods}

In a recently completed comprehensive investigation of spinal cord damaged persons injured more than 20 years ago 832 patient data sets were studied. Six hundred and seventy three of these were from Stoke Mandeville Hospital. Two hundred and forty one of these 673 were comprehensively evaluated. ${ }^{20}$ Apart from the home address at the time of injury this population was unselected.

Correspondence: D Wang, National Spinal Injuries Centre, Stoke Mandeville Hospital, Aylesbury, Buckinghamshire HP21 8AL, UK
All of the 241 patients were requested to re-attend for neurological reassessment and spine and spinal cord MRI scanning. For various reasons only 153 patients were included in this study (Table 1).

Of the 153 patients, 126 were males and 27 females. Their age at the time of study ranged from 37 to 89 with a mean of 54 .

The distribution of patients in relation to level of vertebral injury and Frankel grading at initial neurological stabilisation is indicated in Table 2 .

Table 1 Patient material of the study

\begin{tabular}{lc}
\hline Total number of patients contacted & 241 \\
$\quad \begin{array}{l}\text { Did not respond, declined or } \\
\text { too ill to attend the study }\end{array}$ & 72 \\
$\begin{array}{l}\text { Died } \\
\text { MRI contraindicated }\end{array}$ & 3 \\
$\quad$ (cardiac pacemaker) & 2 \\
$\quad \begin{array}{l}\text { Claustrophobia or } \\
\text { too big for the scanner }\end{array}$ & 6 \\
$\begin{array}{l}\text { Total number of patients who completed } \\
\text { the examination } \\
\quad \text { excluded from the study due to } \\
\text { MRI motion or metal artefact }\end{array}$ & 158 \\
$\begin{array}{l}\text { Total number of patients included in the } \\
\text { study }\end{array}$ & 5 \\
\hline
\end{tabular}


The duration from injury to the time of the study ranged from 21 to 48 years with a mean of 29 .

Eleven of the 153 patients had had spinal surgery shortly after injury. This was laminectomy alone in 2 , laminectomy with dural decompression in 3, laminectomy with internal fixation in 2 and internal fixation alone in 4

The MRI scanner used in this study was a 0.2 Tesla permanent magnet Hitachi MRP 20. In all cases, T1 weighted images of sagittal sections were obtained. T2 weighted images, obtained in 40 patients, and Gadolinium enhancement, given in 41 cases were carefully evaluated and found to add no valuable extra information and so were discontinued at an early stage in the study. This study is based on the T1 weighted images alone. This offers sharper images on our equipment than does $\mathrm{T} 2$ weighted images and is also more accurate for measurement in our experience. An experiment to assess the accuracy of measurements using our equipment showed an under reading of $5 \%$ with $\mathrm{T} 1$ weighted image but of $15 \%$ with $\mathrm{T} 2$ weighted images. The midline sagittal slices were used for analysis. The regions of the spine that were imaged are indicated in Table 3. One hundred and nineteen patients $(78 \%)$ had their cervical, thoracic and lumbar spines scanned.

\section{Definitions}

Spinal cord pathologies analysed include extended atrophy, malacia, syrinx, cyst, disruption and tethering. The definitions of these terms as used in this study are as follows.

Extended atrophy is abnormal narrowing of the spinal cord in the sagittal plane two segments or more beyond the limits of the vertebral injury (Figure 1a and $1 b$ ).

To determine atrophy it was first necessary to determine the range of normal sagittal spinal cord
Table 2 Level of vertebral injury in relation to initial Frankel neurological grade

\begin{tabular}{lccccc}
\hline & \multicolumn{5}{c}{ Frankel grade } \\
\cline { 2 - 6 } $\begin{array}{l}\text { Level of } \\
\text { vertebral injury }\end{array}$ & $A$ & $B$ & $C$ & $D$ & Total \\
\hline Cervical (C1-T1) & 30 & 8 & 7 & 13 & 58 \\
Thoracic (T2-10) & 41 & 0 & 1 & 3 & 45 \\
$\begin{array}{l}\text { Thoracolumbar } \\
\quad \text { and lumbar }\end{array}$ & 29 & 3 & 2 & 16 & 50 \\
$\quad(T 11-\mathrm{L} 5)$ & & & & & \\
$\quad$ Total & 100 & 11 & 10 & 32 & 153 \\
\hline
\end{tabular}

diameters using our scanner. The $\mathrm{T} 1$ scans of 30 patients without spinal cord lesions were reviewed. Following this the lower limit of normal was set at $7.0 \mathrm{~mm}$ for the cervical and $6.0 \mathrm{~mm}$ for the thoracic spinal cord. This accords well with the cadaver studies of Nordqvist. ${ }^{21}$ The extent of atrophy cannot be determined accurately because there is no clear demarcation between cord of normal and reduced calibre.

Malacia is an area of signal intensity that is between that of CSF and normal spinal cord. This signal intensity is decreased on T1 weighted and increased on T2 weighted images with respect to the surrounding cord. Its contour is ill-defined and its shape irregular (Figure $2 \mathrm{a}$ and $2 \mathrm{~b}$ ).

A syrinx (Greek word for tube) is an area with the same signal intensity as CSF (i.e. low T1, high T2). It is tubular, usually tapered at one or both ends and may appear loculated. It has a well-defined contour. It extends beyond the site of maximal bony protrusion into the spinal canal and usually beyond the limits of the vertebral injury (Figure $3 \mathrm{a}$ and $3 \mathrm{~b}$ ). The sagittal extent of a syrinx is measured as the number of vertebral segments spanned.
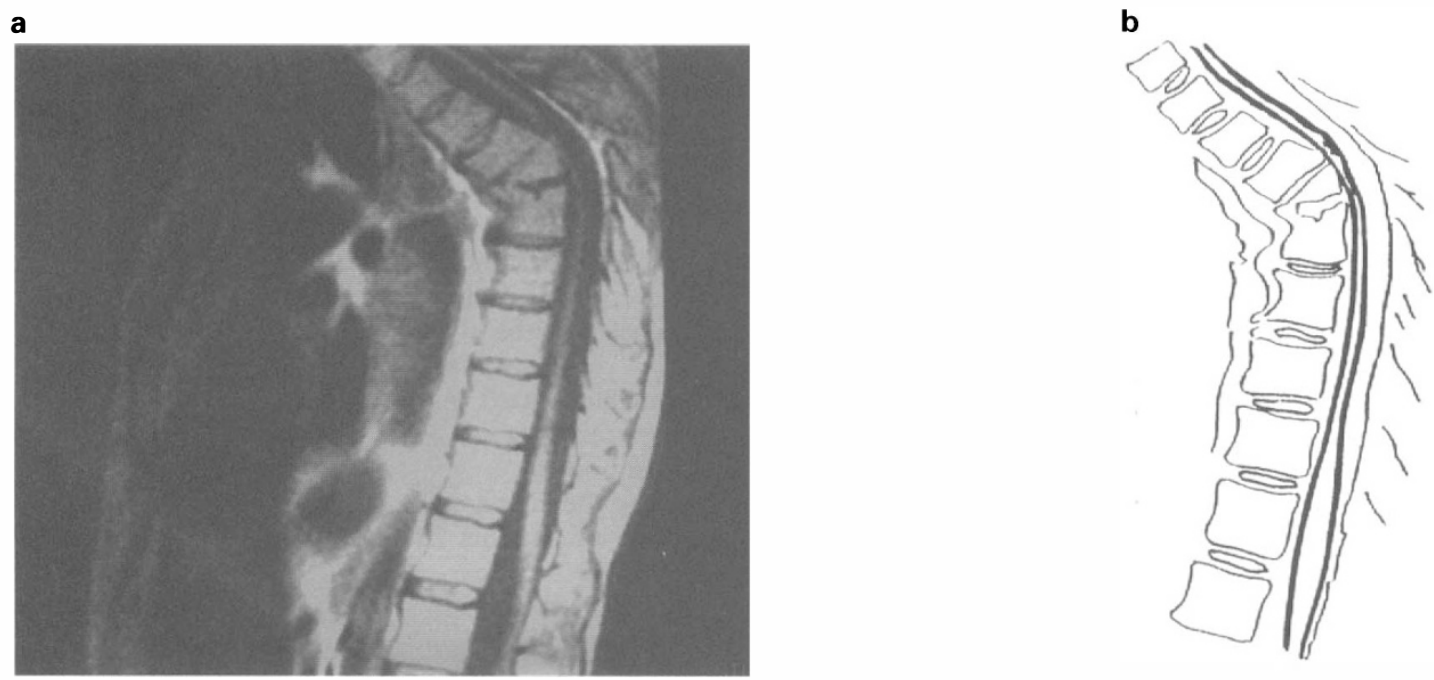

Figure 1 ( $\mathrm{a}$ and $\mathrm{b})$. Atrophy extending both rostrally and caudally from the level of vertebral injury 
A cyst has the same signal intensity and contour definition as a syrinx but differs in that it is round or oval rather than tube-shaped and is confined to the site of maximal bony protrusion into the spinal canal (Figure $4 \mathrm{a}$ and $4 \mathrm{~b}$ ).

Disruption is complete absence of spinal cord signal (Figure $5 \mathrm{a}$ and $5 \mathrm{~b}$ ).

Tethering is attachment of the spinal cord to the wall of the bony spinal canal (Figure 6a and 6b).

No major pathology is used to describe findings at two areas in particular: firstly the area at the level of the conus and cauda equina where it is difficult to tell the difference between malacia and a normal pattern of nerve root distribution and secondly where the cord is atrophied at the level of vertebral injury but is otherwise normal.

Spinal canal compromise is considered to be present at the level of injury where the antero-posterior canal diameter is two thirds or less of the average diameter of the canal opposite the vertebral bodies immediately above and below the injured level. The original spinal $\mathrm{X}$-ray films were compared with the MRI scans to establish whether or not any remodelling of the spinal canal had occurred.

The angulation of the spine adjacent to the level of injury was measured as the angle between the normal

a

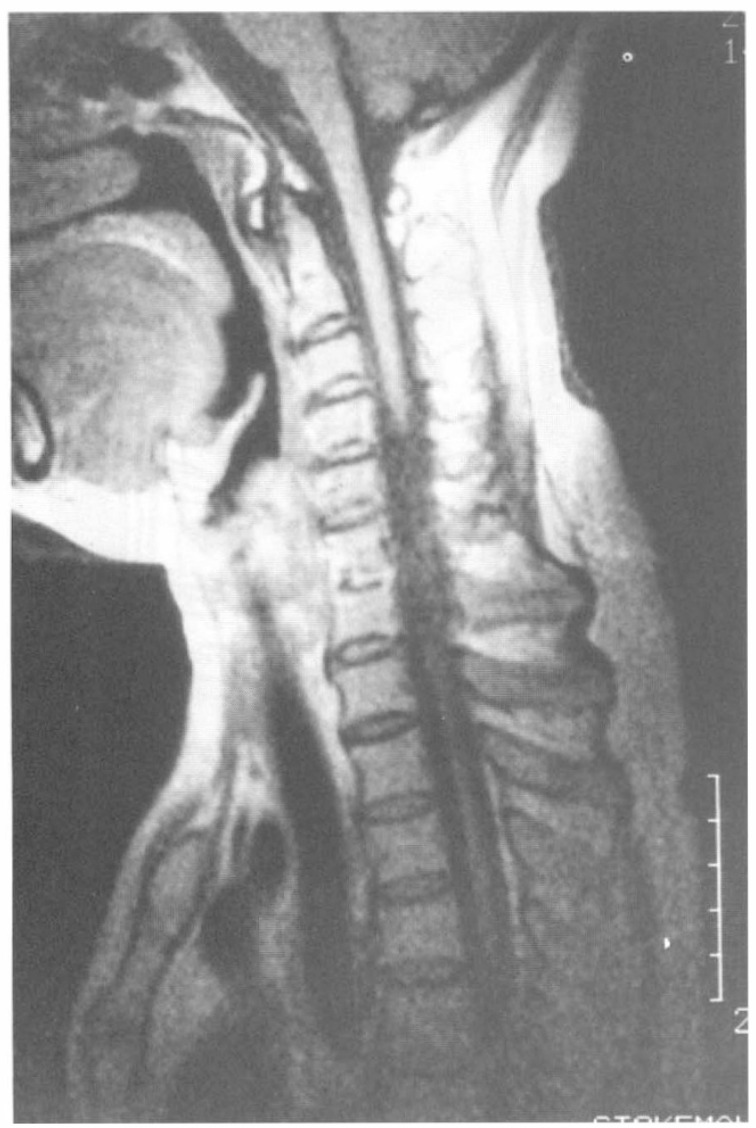

vertebral end-plates immediately above and below the level of injury. Positive numbers indicate kyphosis and negative lordosis. Zero refers to a neutral position which is neither kyphotic nor lordotic. ${ }^{22}$

Degenerative changes of the cervical spine were recorded. Narrowing of the disc space without protrusion or osteophytes is classified as Grade A, protrusion of the disc or osteophytes into the spinal canal without indentation of the cord as Grade B and protrusion of the disc or osteophytes with indentation of the cord as Grade C. The results were studied in relation to extended atrophy.

Clinical examination of each patient comprised a detailed history and a comprehensive neurological examination. It was carried out by a spinal cord injury specialist who had no prior knowledge of the results of the MRI scans. Changes in neurological symptoms and signs (referred to as neurological changes below) since the stage of initial neurological stabilisation were recorded and correlated with the MRI findings. These changes include neurogenic pain, increased spasms, elevation of sensory level and decreased motor power. The term deterioration often used in the literature to describe these changes is not applied in this study (see Results and Discussion). 


\section{Results}

The results are expressed in Tables 4-25. Because any single patient may have more than one pathology and more than one neurological change, the total numbers of each of these variables may exceed the total number of patients.

\section{Spinal cord pathologies on T1 MRI sagittal scans}

The spinal cord pathologies of the 153 patients included, in order of prevalence, extended atrophy, malacia, syrinx, cyst, disruption and tethering. They are shown in Table 4 . Nearly half of the patients $(48.3 \%)$ had a double pathology and $36.6 \%$ had a single pathology. The pattern of combinations is shown in Table 5. It can be seen that the most common combination is extended atrophy and malacia.

Table 6 indicates the relation between the prevalence of these pathologies and the level of vertebral injury. The vertebral injuries are evenly distributed among the cervical, thoracic, and thoracolumbar and lumbar sections, being 58, 45 and 50 respectively. Within each pathology, extended atrophy and cysts are most commonly found in the cervical group, syrinxes, disruption and tethering in the thoracic group and malacia in the thoracolumbar and lumbar group.

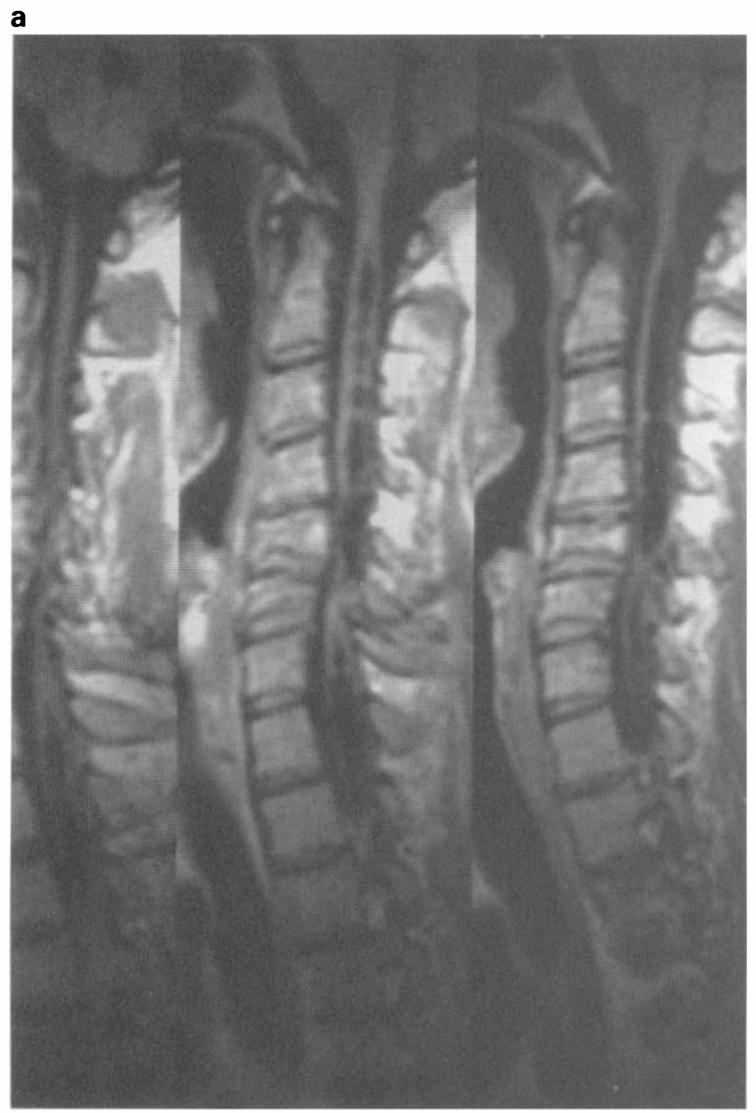

Table 7 shows the relation between the prevalence of these pathologies and the Frankel grading of the initial spinal cord injury. Cysts are relatively evenly distributed among various Frankel gradings whilst the other lesions are mainly associated with Frankel A. Disruption is seen only in Frankel A.

Extended atrophy is the most common lesion. The high prevalence of extended atrophy in the cervical group is of statistical significance when compared with the thoracolumbar and lumbar group. (T11 and below), but not the thoracic group. There is no statistically significant difference between the thoracic and the thoracolumbar and lumbar groups. A preliminary review of MRI scans in another group of patients within 2 years of spinal cord injury did not show such extended atrophy. ${ }^{23}$ This indicates that extended atrophy is a late tertiary change.

The direction of the extension of the atrophy is indicated in Table 8. Rostral and caudal extension is equally common.

Malacia is the second most common lesion. It was confined within the boundaries of the vertebral injury except in 2 cases. It was most commonly seen in the thoracolumbar and lumbar group, though not to a statistically significant extent.

Syrinxes are less common than atrophy or malacia

b

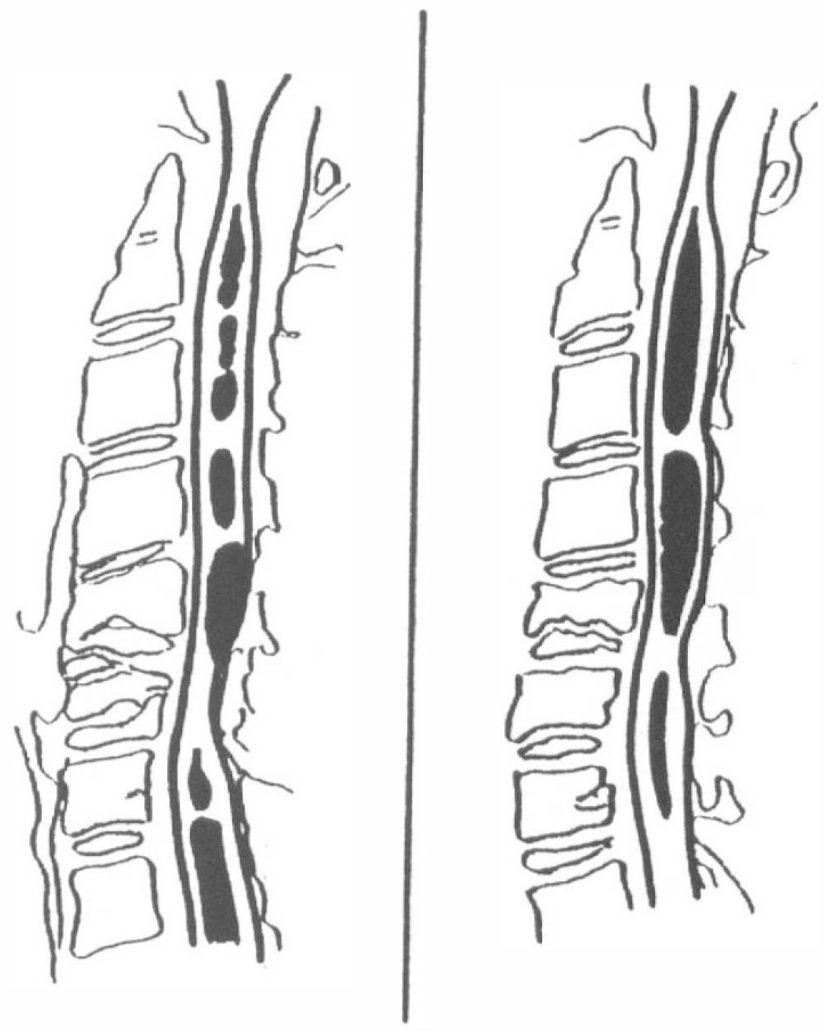

Figure 3 ( $\mathrm{a}$ and $\mathrm{b})$. A syrinx extending both rostrally and caudally from the level of vertebral injury. It is loculated and with a tapered upper end. At the level of maximum bony protrusion there is cord atrophy but no cavitation 
but more common than cysts. The prevalence of syrinxes appears to be highest in the thoracic group though it is of no statistical significance when compared with that of the other two groups.

a

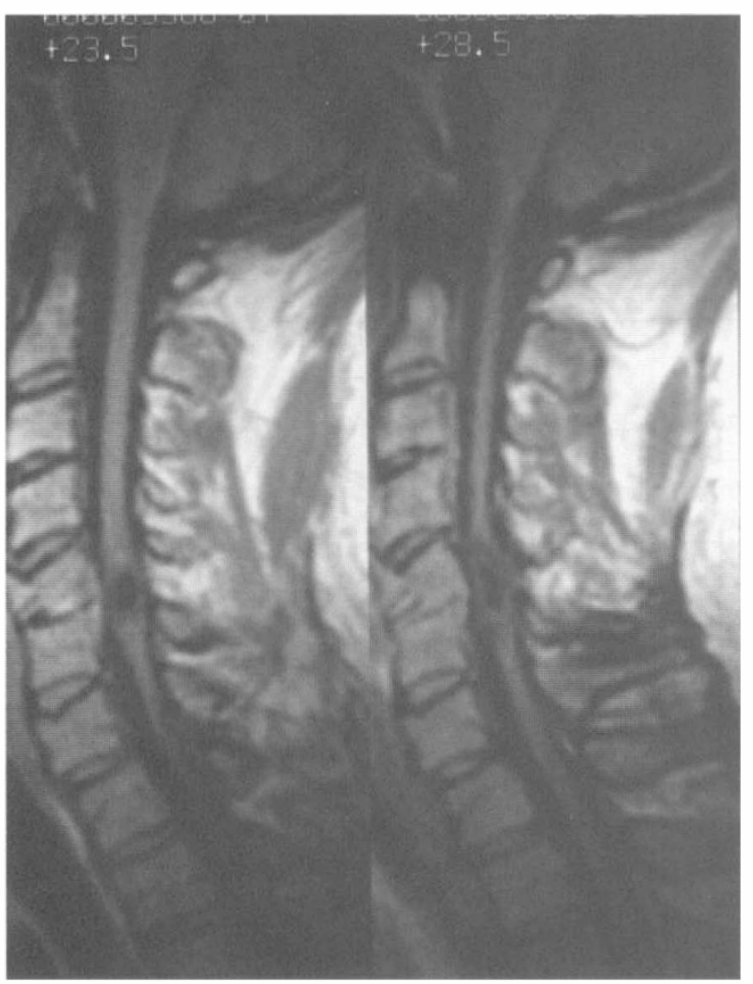

b

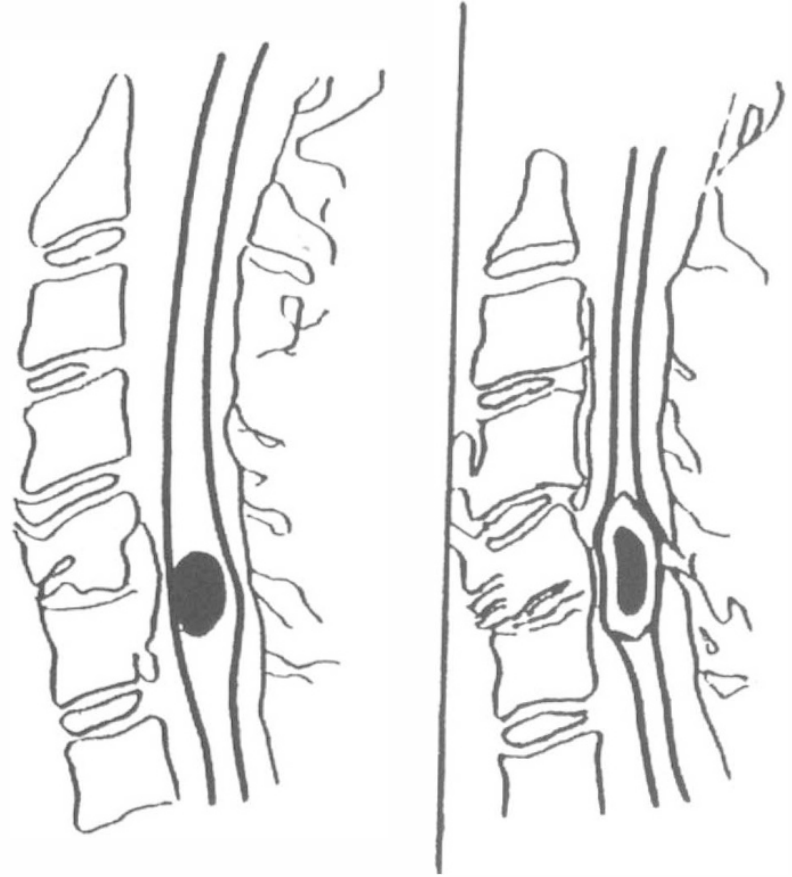

Figure 4 ( $a$ and $b$ ). Two views of the same cyst. This is oval in shape and strictly confined to the site of maximum bony protrusion. A slightly hypointense signal ring is seen around the cavity
The direction of extension of the syrinxes is indicated in Table 9. The numbers of patients with rostral and caudal extension only are equal. The average numbers of segments extending rostrally and caudally beyond the level of vertebral injury are also equal, being 5 segments in both directions. The longitudinal extent of all syrinxes, including those confined to the boundaries of vertebral injury, ranged from 2 to 20 vertebral segments with a mean of 6 segments.

Three syrinxes were diagnosed with myelography or CT myelography and shunted before this study. The MRI scans indicated collapsed syrinxes.

In 4 of the 14 cysts a slightly hypointense T1 signal ring was present (Figure 4a and 4b). An unpublished preliminary review of cases recorded at the National Spinal Injuries Centre within 3 years of injury has failed to identify any cysts with similar features.

Cord disruption was present in 6 cases. Five of these were in the thoracic and one in the thoraco-
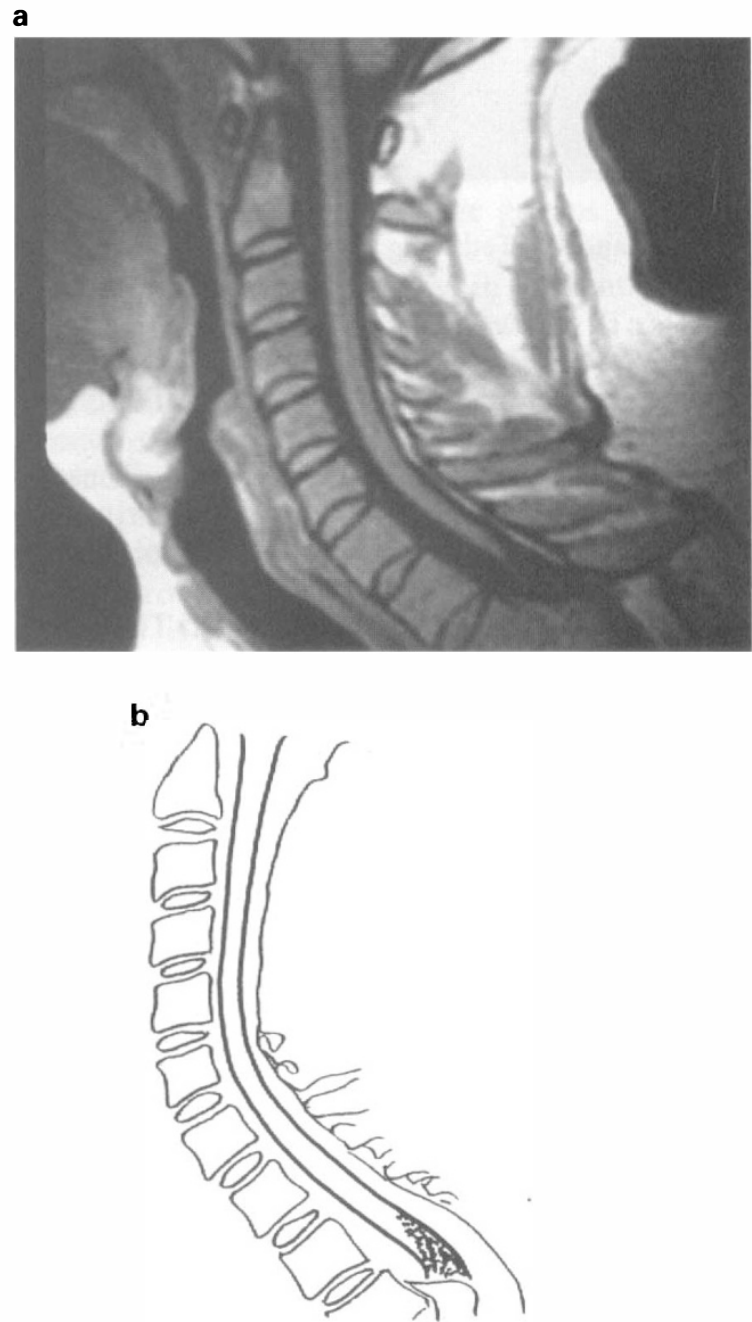

Figure 5 ( $a$ and $b$ ). Disruption of the cord. Spinal cord signal disappears just below the lower end of the upper thoracic spinal cord 


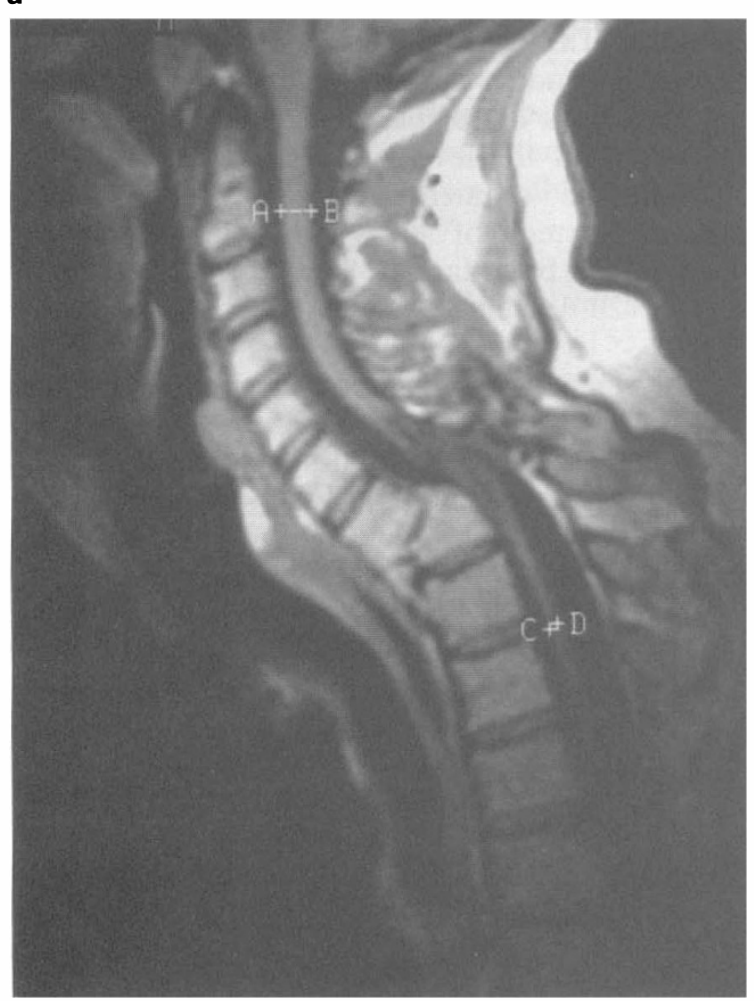

b

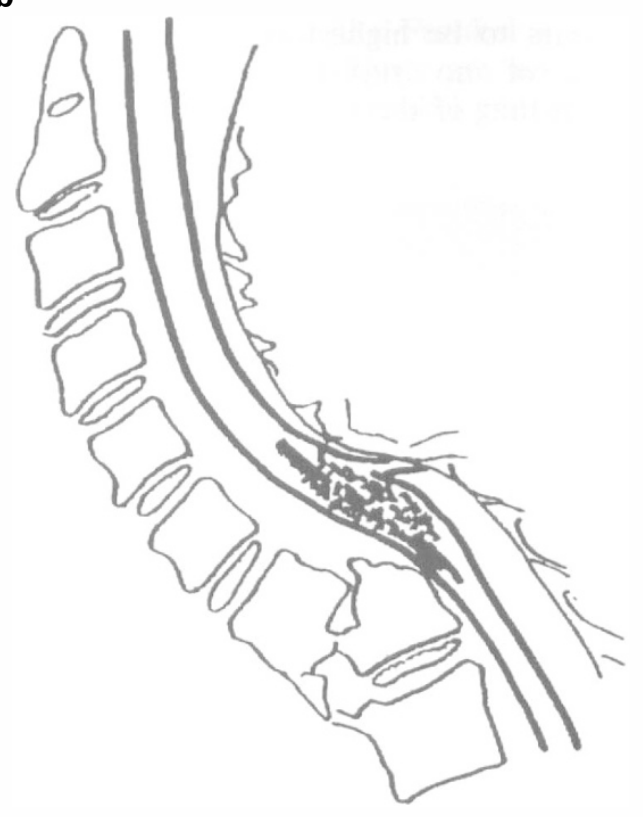

Figure 6 ( $\mathrm{a}$ and $\mathrm{b}$ ). Tethering of the cord attached to the posterior wall of the spinal canal

lumbar level. The relation between this and other lesions is shown in Table 10. Cyst and tethering were not seen in the disruption group. In two cases the disruption was associated with a syrinx. These two syrinxes were among the smallest of all syrinxes and occupied only two and three segments respectively. Both were asymptomatic.

Tethering was present in 6 patients. The relation between tethering, spinal cord pathologies and surgery within the spinal dural sac is shown in Table 11. All 6 patients had a combination of pathologies in addition to tethering. The most common associated pathology was atrophy. In patient $E$ the tethering was seen at the site of drainage of the syrinx.

The number of each pathology in relation to years after injury is indicated in Table 12. There is no significant difference in the prevalence of pathologies

Table 3 Regions of spine scanned

\begin{tabular}{lc}
\hline Regions & Number of patients \\
\hline Cervical, thoracic and lumbar & 119 \\
Cervical and thoracic & 13 \\
Cervical alone & 14 \\
Thoracic alone & 2 \\
Thoracic and lumbar & 4 \\
Lumbar alone & 1 \\
Total & 153 \\
\hline
\end{tabular}

Table 4 Type of pathology of the spinal cord seen in MRI

\begin{tabular}{lrl}
\hline Type of pathology & Number of patients (\%) \\
\hline Extended atrophy & 95 & $(62.1)$ \\
Malacia & 85 & $(55.6)$ \\
Syrinx & 32 & $(20.9)$ \\
Cyst & 14 & $(9.1)$ \\
Disruption & 6 & $(3.9)$ \\
Tethering & 6 & $(3.9)$ \\
No major pathology & 13 & $(8.5)$ \\
Total & 153
\end{tabular}

Note: The percentage of each pathology is calculated independently against the total number of patients. There is no cross relation between these percentages

Table 5 Pattern of spinal cord pathologies

\begin{tabular}{lcc}
\hline Pattern of pathologies & Number of patients (\%) \\
\hline Single pathology & 56 & $(36.6)$ \\
Double pathology & 74 & $(48.4)$ \\
$\quad$ extended atrophy + malacia & & 45 \\
extended atrophy + syrinx & & 14 \\
extended atrophy + cyst & & 7 \\
other combinations & & 8 \\
Triple pathology & 9 & $(5.9)$ \\
Quadruple pathology & 1 & $(<1.0)$ \\
No major pathology & 13 & $(8.5)$ \\
Total & 153 & $(100)$ \\
\hline
\end{tabular}


Table 6 Distribution of various pathologies at various levels of vertebral injury

\begin{tabular}{|c|c|c|c|c|c|c|}
\hline \multirow{2}{*}{ Type of pathology } & \multicolumn{6}{|c|}{$\begin{array}{l}\text { Number of patients }(\%) \\
\text { at various levels of vertebral injury }\end{array}$} \\
\hline & \multicolumn{2}{|c|}{ Cervical } & \multicolumn{2}{|c|}{ Thoracic } & \multicolumn{2}{|c|}{$\begin{array}{l}\text { Thoracolumbar } \\
\text { and lumbar }\end{array}$} \\
\hline Extended atrophy & 47 & $(81.0)$ & & $(64.4)$ & 19 & $(38.0)$ \\
\hline Malacia & & $(48.3)$ & 24 & $(53.3)$ & 33 & $(66.0)$ \\
\hline Syrinx & 12 & $(20.7)$ & 14 & (31.1) & 6 & $(12.0)$ \\
\hline Cyst & & $(15.5)$ & & $(4.4)$ & 3 & $(6.0)$ \\
\hline Disruption & & 0 & & (11.1) & 1 & $(2.0)$ \\
\hline Tethering & 3 & $(5.2)$ & & $(6.7)$ & & 0 \\
\hline $\begin{array}{l}\text { Total at various levels of } \\
\text { vertebral injury }\end{array}$ & & 58 & & 45 & & 50 \\
\hline
\end{tabular}

Table 7 Distribution of various pathologies in various Frankel grades

\begin{tabular}{|c|c|c|c|c|c|}
\hline \multirow{2}{*}{$\begin{array}{l}\text { Type of } \\
\text { pathology }\end{array}$} & \multicolumn{5}{|c|}{ Number of patients in various Frankel grades } \\
\hline & $A$ & $B$ & $C$ & $D$ & Total \\
\hline $\begin{array}{l}\text { Extended } \\
\text { atrophy }\end{array}$ & 69 & 6 & 8 & 12 & 95 \\
\hline Malacia & 60 & 5 & 3 & 17 & 85 \\
\hline Syrinx & 28 & 1 & 1 & 2 & 32 \\
\hline Cyst & 6 & 4 & 2 & 2 & 14 \\
\hline Disruption & 6 & 0 & 0 & 0 & 6 \\
\hline Tethering & 4 & 2 & 0 & 0 & 6 \\
\hline Total & 100 & 11 & 10 & 32 & 153 \\
\hline
\end{tabular}

Table 8 Direction of extension of atrophy

\begin{tabular}{lc}
\hline Direction & Number of patients \\
\hline Rostral only & 32 \\
Caudal only & 31 \\
Rostral and caudal & 32 \\
Total & 95 \\
\hline
\end{tabular}

Table 9 Direction of extension of syrinxes

\begin{tabular}{lc}
\hline Direction & Number of patients \\
\hline Rostral only & 11 \\
Caudal only & 11 \\
Rostral and caudal & 7 \\
Within the boundaries of & 3 \\
$\quad$ vertebral injury & 32 \\
Total & \\
\hline
\end{tabular}

between different periods post injury. It appears, however, that the prevalence of syrinxes is higher whilst that of atrophy, malacia and cysts lower in the $30-39$ year post injury group compared with the $20-$ 29 year group.

Table 13 shows a significant increase in the number of syrinxes in thoracic patients 30-39 year post injury compared with a fall in cervical patients.

The relation between the age of patients at the time of this study and the prevalence of each pathology is shown in Table 14. There is no difference of statistical significance between different age groups.

Spinal canal compromise was seen in 79 patients. The distribution of pathology in patients with and without such compromise is shown in Table 15. In only two patients was there any remodelling of the spinal canal on the MRI scan compared with the original spinal $\mathrm{X}$-ray films and this was minimal. These do not significantly affect the result of the statistical analysis. There is no statistically significant difference in the number of each pathology between the two groups except cord disruption which not surprisingly is invariably associated with spinal canal compromise.

The relations between the degree of angulation of the various sections of the spine and the pathologies are presented in Tables 16, 17 and 18. There is no statistically significant difference in the prevalence of each pathology between groups of various degrees of angulation.

All 146 patients who had their cervical spine scanned showed degenerative changes of the spine.

Table 10 Relation between disruption and other pathologies

\begin{tabular}{|c|c|c|c|c|c|}
\hline \multirow{2}{*}{$\begin{array}{l}\text { Status of } \\
\text { continuity of the } \\
\text { spinal cord }\end{array}$} & \multicolumn{5}{|c|}{ Number of patients with each pathology } \\
\hline & $\begin{array}{l}\text { Extended } \\
\text { atrophy }\end{array}$ & Malacia & Syrinx & Cyst & Tethering \\
\hline $\begin{array}{l}\text { Disruption } \\
\quad(6 \text { patients })\end{array}$ & 4 & 4 & 2 & 0 & 0 \\
\hline $\begin{array}{l}\text { No disruption } \\
\text { (147 patients) }\end{array}$ & 91 & 81 & 30 & 14 & 6 \\
\hline Total (153) & 95 & 85 & 32 & 14 & 6 \\
\hline
\end{tabular}


Table 11 Tethering in relation to other pathologies and surgery within the spinal dural sac (6 patients)

\begin{tabular}{lcccccc}
\hline Patient & Atrophy & Malacia & Syrinx & Cyst & Disruption & Surgery \\
\hline A & yes & yes & - & - & - & - \\
B & yes & yes & - & - & - & - \\
C & yes & - & - & yes & - & - \\
D & yes & - & - & yes & - & - \\
E & yes & - & yes & - & - & yes \\
F & - & - & - & yes & - & - \\
\hline
\end{tabular}

Six patients had Grade A, 135 Grade B and 5 Grade C degeneration. None of the five patients with Grade $\mathrm{C}$ degeneration, the most severe change, had associated extended atrophy despite the fact that 3 of them had changes involving between 4 and 6 intervertebral spaces.

\section{Neurological change after initial neurological stabilisation}

Thirty five patients $(23 \%)$ had had changes in their neurological condition after initial neurological stabilisation. These include neurogenic pain in 22 , increased spasms in 10, elevation of sensory level in 7 and decreased motor power in 3. As some patients had more than one change the total number of changes exceeds the number of patients.

Table 12 Pathology in relation to year post injury

\begin{tabular}{|c|c|c|c|c|c|}
\hline \multirow{3}{*}{$\begin{array}{l}\text { Type of } \\
\text { pathology } \\
\text { Extended atrophy }\end{array}$} & \multicolumn{5}{|c|}{$\begin{array}{c}\text { Number and percentage }(\%) \text { of patients } \\
\text { with each pathology } \\
\text { in various post injury year groups }\end{array}$} \\
\hline & \multicolumn{2}{|c|}{$20-29$} & \multicolumn{2}{|c|}{$30-39$} & \multirow{2}{*}{$\frac{40+}{6}$} \\
\hline & 62 & $(68.1)$ & 27 & $(50.9)$ & \\
\hline Malacia & 55 & $(60.4)$ & 25 & $(47.2)$ & 5 \\
\hline Syrinx & 17 & $(18.7)$ & 13 & $(24.5)$ & 2 \\
\hline Cyst & & 10 & & 4 & 0 \\
\hline Disruption & & 2 & & 4 & 0 \\
\hline Tethering & & 2 & & 3 & 0 \\
\hline No major pathology & & 6 & & 7 & 0 \\
\hline $\begin{array}{l}\text { Total number of } \\
\text { patients }\end{array}$ & & 91 & & 53 & 9 \\
\hline
\end{tabular}

Notes: 1. No statistically significant difference among all groups. 2. Percentage is not given with small numbers
Table 14 Pathology in relation to age at the time of the study

\begin{tabular}{lccccc}
\hline \multirow{2}{*}{$\begin{array}{l}\text { Type of } \\
\text { pathology }\end{array}$} & \multicolumn{5}{c}{ Number of patients of various age groups } \\
\cline { 2 - 6 } & $<40$ & $40-49$ & $50-59$ & $60-69$ & $70+$ \\
\hline $\begin{array}{l}\text { Extended } \\
\quad \text { atrophy }\end{array}$ & 3 & 28 & 3 & 18 & 8 \\
Malacia & 2 & 29 & 34 & 15 & 5 \\
Syrinx & 2 & 8 & 15 & 7 & 0 \\
Cyst & 0 & 5 & 6 & 3 & 0 \\
Disruption & 0 & 2 & 2 & 2 & 0 \\
Tethering & 0 & 1 & 4 & 1 & 0 \\
No major & 0 & 4 & 5 & 4 & 0 \\
$\quad \begin{array}{c}\text { pathology } \\
\text { Total number of } \\
\text { patients }\end{array}$ & 4 & 46 & 64 & 29 & 10
\end{tabular}

Note: No statistically significant difference among all groups

Table 15 Relation between spinal canal compromise and prevalence of pathology

\begin{tabular}{lccc}
\hline & \multicolumn{2}{c}{ Spinal canal compromise } & \\
\cline { 2 - 3 } Type of pathology & $y e s$ & $n o$ & Total \\
\hline Extended atrophy & 50 & 45 & 95 \\
Malacia & 52 & 33 & 85 \\
Syrinx & 18 & 14 & 32 \\
Cyst & 6 & 8 & 14 \\
Disruption & 6 & 0 & 6 \\
Tethering & 4 & 2 & 6 \\
No major pathology & 9 & 4 & 13 \\
Total number of & 79 & 74 & 153 \\
$\quad$ patients & & & \\
Note: No statistically significant difference among all groups
\end{tabular}

Table 13 Relation between year post injury and prevalence of syrinx at various levels of vertebral injury

\begin{tabular}{|c|c|c|c|c|}
\hline \multirow{2}{*}{$\begin{array}{l}\text { Level of } \\
\text { vertebral } \\
\text { injury }\end{array}$} & \multirow{2}{*}{$\begin{array}{c}\text { Number of } \\
\text { patients with } \\
\text { various levels } \\
\text { of vertebral } \\
\text { injury }\end{array}$} & \multicolumn{3}{|c|}{$\begin{array}{l}\text { Total number of patients vs } \\
\text { number of patients with syrinx (in bracket) } \\
\text { in various post injury year groups }\end{array}$} \\
\hline & & $20-29$ & $30-39$ & $40+$ \\
\hline Cervical & 58 & $43 \quad(10)^{*}$ & $15 \quad(2)^{*}$ & $0 \quad(0)$ \\
\hline Thoracic & 45 & $17 \quad(6)^{*}$ & $23 \quad(11)^{*}$ & $5 \quad(0)$ \\
\hline $\begin{array}{c}\text { Thoracolumbar } \\
\text { and lumbar }\end{array}$ & 54 & $31 \quad(1)$ & $15(0)$ & $4(2)$ \\
\hline Total & 153 & $91 \quad(17)$ & $53 \quad(13)$ & $9 \quad(2)$ \\
\hline
\end{tabular}

* Significant difference $(P=0.024)$ 
Table 16 Relation between degree of angulation of cervical spine and prevalence of pathology

\begin{tabular}{|c|c|c|c|c|c|}
\hline \multirow{2}{*}{$\begin{array}{l}\text { Type of } \\
\text { pathology }\end{array}$} & \multicolumn{4}{|c|}{$\begin{array}{c}\text { Number of patients } \\
\text { with various degrees of angulation }\end{array}$} & \multirow[b]{2}{*}{ Total } \\
\hline & $0-$ & $1-22$ & $23-44$ & $45+$ & \\
\hline $\begin{array}{l}\text { Extended } \\
\text { atrophy }\end{array}$ & 38 & 4 & 4 & 1 & 47 \\
\hline Malacia & 24 & 1 & 3 & 0 & 28 \\
\hline Syrinx & 8 & 2 & 1 & 1 & 12 \\
\hline Cyst & 8 & 1 & 0 & 0 & 9 \\
\hline Disruption & 0 & 0 & 0 & 0 & 0 \\
\hline Tethering & 3 & 0 & 1 & 0 & 4 \\
\hline $\begin{array}{l}\text { No major } \\
\text { pathology }\end{array}$ & 3 & 1 & 0 & 0 & 4 \\
\hline $\begin{array}{l}\text { Total number of } \\
\text { patients }\end{array}$ & 48 & 5 & 4 & 1 & 58 \\
\hline
\end{tabular}

Notes: 1. $<0=$ lordosis, $0=$ neutral, $>0=$ kyphosis. 2. $\overline{\text { No }}$ statistically significant difference among all groups

Table 17 Relation between degree of kyphosis of thoracic spine and prevalence of pathology

\begin{tabular}{|c|c|c|c|c|}
\hline \multirow{2}{*}{$\begin{array}{l}\text { Type of } \\
\text { pathology }\end{array}$} & \multicolumn{3}{|c|}{$\begin{array}{c}\text { Number of patients } \\
\text { with various degrees of kyphosis }\end{array}$} & \multirow[b]{2}{*}{ Total } \\
\hline & $1-22$ & $23-44$ & $45+$ & \\
\hline $\begin{array}{l}\text { Extended } \\
\text { atrophy }\end{array}$ & 13 & 12 & 4 & 39 \\
\hline Malacia & 7 & 11 & 6 & 24 \\
\hline Syrinx & 1 & 4 & 9 & 14 \\
\hline Cyst & 1 & 0 & 1 & 2 \\
\hline Disruption & 0 & 1 & 4 & 5 \\
\hline Tethering & 0 & 2 & 0 & 2 \\
\hline $\begin{array}{l}\text { No major } \\
\text { pathology }\end{array}$ & 0 & 0 & 1 & 1 \\
\hline $\begin{array}{l}\text { Total number of } \\
\text { patients }\end{array}$ & 12 & 10 & 23 & 45 \\
\hline
\end{tabular}

The mean ages of patients with pain and spasms are 54 and 60 respectively. The former is equal to whilst the latter is greater than the mean of patients without neurological change. The mean ages of patients with elevation of sensory level and decreased motor power are less than the mean age of patients without neurological change, being 53 and 50 respectively. The difference is of no statistical significance.

The distribution of patients with neurological change after initial neurological stabilisation amongst the different pathologies is shown in Table 19. The occurrence of neurological changes is higher with the syrinx than the other groups. With atrophy and malacia pain predominates while with syrinxes elevation of sensory level is as common as pain. The 3 patients in the atrophy group and the one patient in the malacia group who had elevation of sensory level were all associated with syrinx. Cord disruption even in combination with other pathologies was not

Table 18 Relation between degree of angulation of thoracolumbar and lumbar spine and prevalence of pathology

\begin{tabular}{|c|c|c|c|c|c|}
\hline \multirow{2}{*}{$\begin{array}{l}\text { Type of } \\
\text { pathology }\end{array}$} & \multicolumn{4}{|c|}{$\begin{array}{c}\text { Number of patients } \\
\text { with various degrees of angulation }\end{array}$} & \multirow[b]{2}{*}{ Tota } \\
\hline & $0-$ & $1-22$ & $23-44$ & $45+$ & \\
\hline $\begin{array}{l}\text { Extended } \\
\text { atrophy }\end{array}$ & 11 & 4 & 2 & 2 & 19 \\
\hline Malacia & 81 & 5 & 8 & 2 & 33 \\
\hline Syrinx & 3 & 1 & 2 & 0 & 6 \\
\hline Cyst & 3 & 0 & 0 & 0 & 3 \\
\hline Disruption & 1 & 0 & 0 & 0 & 1 \\
\hline Tethering & 0 & 0 & 0 & 0 & 0 \\
\hline $\begin{array}{l}\text { No major } \\
\text { pathology }\end{array}$ & 5 & 2 & 1 & 0 & 8 \\
\hline $\begin{array}{l}\text { Total number } \\
\text { of patients }\end{array}$ & 29 & 8 & 10 & 3 & 50 \\
\hline
\end{tabular}

Table 19 Patients with neurological changes in relation to pathologies

\begin{tabular}{|c|c|c|c|c|c|c|}
\hline \multirow[b]{2}{*}{$\begin{array}{l}\text { Type of } \\
\text { pathology }\end{array}$} & \multirow{2}{*}{$\begin{array}{c}\text { Total number } \\
\text { of patients } \\
\text { with each } \\
\text { pathology }\end{array}$} & \multirow{2}{*}{$\begin{array}{l}\text { Total number } \\
\text { of patients } \\
\text { with all } \\
\text { neurological } \\
\text { changes }(\%)\end{array}$} & \multicolumn{4}{|c|}{$\begin{array}{c}\text { Number of patients with each neurological change } \\
\text { in various pathologies }\end{array}$} \\
\hline & & & $\begin{array}{l}\text { Neurogenic } \\
\text { pain }\end{array}$ & $\begin{array}{l}\text { Increased } \\
\text { spasm }\end{array}$ & $\begin{array}{l}\text { Elevation of } \\
\text { sensory level }\end{array}$ & $\begin{array}{l}\text { Decrease of } \\
\text { motor power }\end{array}$ \\
\hline Extended atrophy & 95 & $25 \quad(26)$ & 16 & 8 & 3 & 3 \\
\hline Malacia & 85 & $18 \quad(21)$ & 13 & 4 & 1 & 2 \\
\hline Syrinx & 32 & 14 (43) & 6 & 4 & 7 & 2 \\
\hline Cyst & 14 & 3 (21) & 3 & 1 & 0 & 1 \\
\hline Disruption & 6 & 0 & 0 & 0 & 0 & 0 \\
\hline Tethering & 6 & $2 \quad(33)$ & 1 & 1 & 1 & 1 \\
\hline No major pathology & 12 & 0 & 0 & 0 & 0 & 0 \\
\hline Total & 153 & 35 & 22 & 10 & 7 & 3 \\
\hline
\end{tabular}


associated with neurological change. It will be recalled that most patients had more than one pathology. In these cases it is not possible to state which pathology, if any, is responsible for the neurological change observed.

Eight patients with neurological change had a single pathology (see Table 20) which was either extended atrophy, malacia or a syrinx. Decreased motor power and elevation of sensory level were seen only with syrinxes whilst the only changes observed with atrophy and malacia were pain and spasms. A cyst or cord disruption on its own was not associated with neurological change. It will be recalled that tethering was always associated with intrinsic spinal cord pathology or pathologies.

Thirty two patients had a syrinx. The average vertebral extent of the syrinx was 8.5 segments in the 15 with neurological change and 4.6 in the 17 without. This difference is statistically significant $(P=0.046)$.

The direction of extension of the syrinx in patients with neurological change is evenly distributed (see Table 21). Sensory and motor changes are associated

Table 20 Patients with a single pathology and neurological change

\begin{tabular}{lccccc}
\hline \multicolumn{5}{c}{$\begin{array}{c}\text { Number of patients } \\
\text { various neurological changes }\end{array}$} \\
\cline { 2 - 5 } $\begin{array}{l}\text { Type of } \\
\text { pathology }\end{array}$ & $\begin{array}{c}\text { Neurogenic } \\
\text { pain }\end{array}$ & $\begin{array}{c}\text { Increased } \\
\text { spasm }\end{array}$ & $\begin{array}{c}\text { Elevation of } \\
\text { sensory level }\end{array}$ & $\begin{array}{c}\text { Decreased } \\
\text { motor power }\end{array}$ & Total \\
Extended atrophy & 1 & 1 & 0 & 0 & 2 \\
Malacia & 3 & 1 & 0 & 0 & 4 \\
Syrinx & 0 & 0 & 2 & 1 & 2 \\
Cyst & 0 & 0 & 0 & 0 & 0 \\
Disruption & 0 & 0 & 0 & 0 & 0 \\
\hline
\end{tabular}

Table 21 Relation between direction of extension of syrinx and neurological change

\begin{tabular}{|c|c|c|c|c|c|}
\hline \multirow[b]{2}{*}{$\begin{array}{l}\text { Direction of } \\
\text { extension of } \\
\text { syrinx }\end{array}$} & \multirow{2}{*}{$\begin{array}{c}\text { Number of } \\
\text { patients } \\
\text { in various } \\
\text { directions }\end{array}$} & \multicolumn{4}{|c|}{$\begin{array}{l}\text { Number of patients with } \\
\text { various neurological changes }\end{array}$} \\
\hline & & $\begin{array}{c}\text { Neurogenic } \\
\text { pain }\end{array}$ & $\begin{array}{c}\text { Increased } \\
\text { spasm }\end{array}$ & $\begin{array}{l}\text { Elevation of } \\
\text { sensory level }\end{array}$ & $\begin{array}{c}\text { Decreased } \\
\text { motor power }\end{array}$ \\
\hline Rostral only & 5 & 0 & 1 & 5 & 2 \\
\hline Caudal only & 5 & 3 & 2 & 0 & 0 \\
\hline Rostral and caudal & 4 & 2 & 0 & 2 & 0 \\
\hline $\begin{array}{l}\text { Within the boundaries } \\
\text { of vertebral injury }\end{array}$ & 1 & 1 & 1 & 0 & 0 \\
\hline
\end{tabular}

Table 22 Relation between spinal canal compromise and neurological change in each pathology

\begin{tabular}{|c|c|c|c|c|}
\hline $\begin{array}{l}\text { Type of } \\
\text { pathology }\end{array}$ & $\begin{array}{l}\text { Number of } \\
\text { patients } \\
\text { of each } \\
\text { pathology }\end{array}$ & $\begin{array}{c}\text { Status of } \\
\text { spinal canal } \\
\text { compromise }\end{array}$ & $\begin{array}{l}\text { Number of } \\
\text { patients with } \\
\text { and without } \\
\text { compromise }\end{array}$ & $\begin{array}{c}\text { Number of } \\
\text { patients with } \\
\text { neurological } \\
\text { changes }\end{array}$ \\
\hline \multirow[t]{2}{*}{ Extended atrophy } & 95 & yes & 50 & 11 \\
\hline & & no & 45 & 16 \\
\hline \multirow[t]{2}{*}{ Malacia } & 85 & yes & 52 & 10 \\
\hline & & no & 33 & 11 \\
\hline \multirow[t]{2}{*}{ Syrinx } & 32 & yes & 18 & 6 \\
\hline & & no & 14 & 9 \\
\hline \multirow[t]{2}{*}{ Cyst } & 14 & yes & 6 & 3 \\
\hline & & no & 8 & 1 \\
\hline \multirow[t]{2}{*}{ Disruption } & 6 & yes & 6 & 0 \\
\hline & & no & 0 & 0 \\
\hline \multirow[t]{2}{*}{ Tethering } & 6 & yes & 4 & 1 \\
\hline & & no & 2 & 0 \\
\hline \multirow[t]{2}{*}{ No major pathology } & 13 & yes & 4 & 0 \\
\hline & & no & 9 & 0 \\
\hline
\end{tabular}

Note: No statistically significant difference among all groups 
only with rostral extension. Pain and spasms are more common with caudal extension. The number of patients with each symptom or sign is too small for statistical analysis.

The relation between spinal canal compromise and neurological change is indicated in Table 22. There is no statistically significant difference between the groups with and without compromise.

The relation between the degree of angulation of various sections of the spine and neurological change is shown in Tables 23, 24 and 25 . There is no significant difference.

The number of patients who had spinal surgery in the early stage following injury is too small to draw any statistical conclusion regarding any altered incidence of spinal cord pathology in the chronic stage.

Table 23 Relation between degree of angulation of cervical spine and neurological change

\begin{tabular}{lcc}
\hline $\begin{array}{l}\text { Degree of } \\
\text { angulation }\end{array}$ & $\begin{array}{c}\text { Total number } \\
\text { of patients }\end{array}$ & $\begin{array}{c}\text { Number of patients } \\
\text { with neurological changes }\end{array}$ \\
\hline $0-$ & 48 & 11 \\
$1-22$ & 1 & 0 \\
$24-44$ & 2 & 1 \\
$45+$ & 7 & 2 \\
Total & 58 & 14 \\
\hline
\end{tabular}

Notes: $1 .<0=$ lordosis, $0=$ neutral, $>0=$ kyphosis. 2. No statistically significant difference among all groups

Table 24 Relation between degree of kyphosis of thoracic spine and neurological change

\begin{tabular}{lcc}
\hline $\begin{array}{l}\text { Degree of } \\
\text { kyphosis }\end{array}$ & $\begin{array}{c}\text { Total number } \\
\text { of patients }\end{array}$ & $\begin{array}{c}\text { Number of patients } \\
\text { with neurological change }\end{array}$ \\
\hline $1-22$ & 11 & 3 \\
$24-44$ & 11 & 6 \\
$45+$ & 23 & 7 \\
Total & 45 & 13 \\
\hline
\end{tabular}

Notes: 1. There is no lordosis and neutral position of the spine in this group. 2. No statistically significant difference among all groups

Table 25 Relation between degree of angulation of thoracolumbar and lumbar spine and neurological change

\begin{tabular}{lcc}
\hline $\begin{array}{l}\text { Degree of } \\
\text { angulation }\end{array}$ & $\begin{array}{c}\text { Total number } \\
\text { of patients }\end{array}$ & $\begin{array}{c}\text { Number of patients } \\
\text { with neurological changes }\end{array}$ \\
\hline $0-$ & 29 & 3 \\
$1-22$ & 8 & 0 \\
$24-44$ & 10 & 4 \\
$45+$ & 3 & 1 \\
Total & 50 & 8
\end{tabular}

Notes: $1 .<0=$ lordosis, $0=$ neutral, $>0=$ kyphosis. 2 . No statistically significant difference among all groups
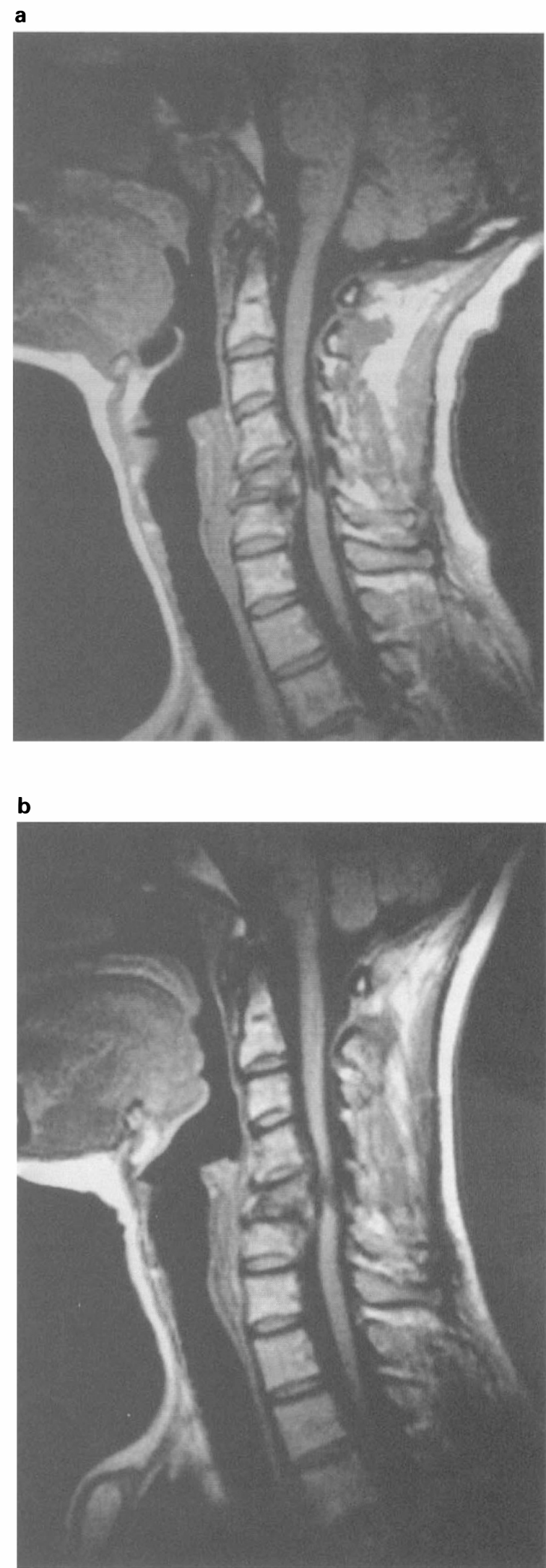

Figure 7 (a). A segmental low signal area suggesting ischaemia. (b). A centrally located malacic focus two years later in the same patient as in $7 \mathrm{a}$ 
Two patients in this study had features suggesting that vascular myelopathy could be a precursor of malacia and subsequently syrinx formation. In the first patient a focus of centrally located linear malacia developed (Figure 7a) where an earlier scan had revealed a segmental low signal area suggestive of ischaemia (Figure 7b). In the second a series of longitudinal malacic foci far removed from the original site of injury were seen above a shunted and collapsed syrinx (Figure 8).

\section{Discussion}

A number of reports have been published in the literature involving MRI scanning in patients with chronic spinal cord injury. ${ }^{1-11}$ This series is the largest yet published. The definitions of lesions used by each author were different and sometimes difficult to compare even in the same paper. Understanding is hampered by disagreement not only on the MRI changes but also, more fundamentally, on the pathological changes that occur.

Because isolated cases of discrepancy between the MRI image and the pathology seen either at surgery or necropsy have been reported and observed, ${ }^{1,24,25}$

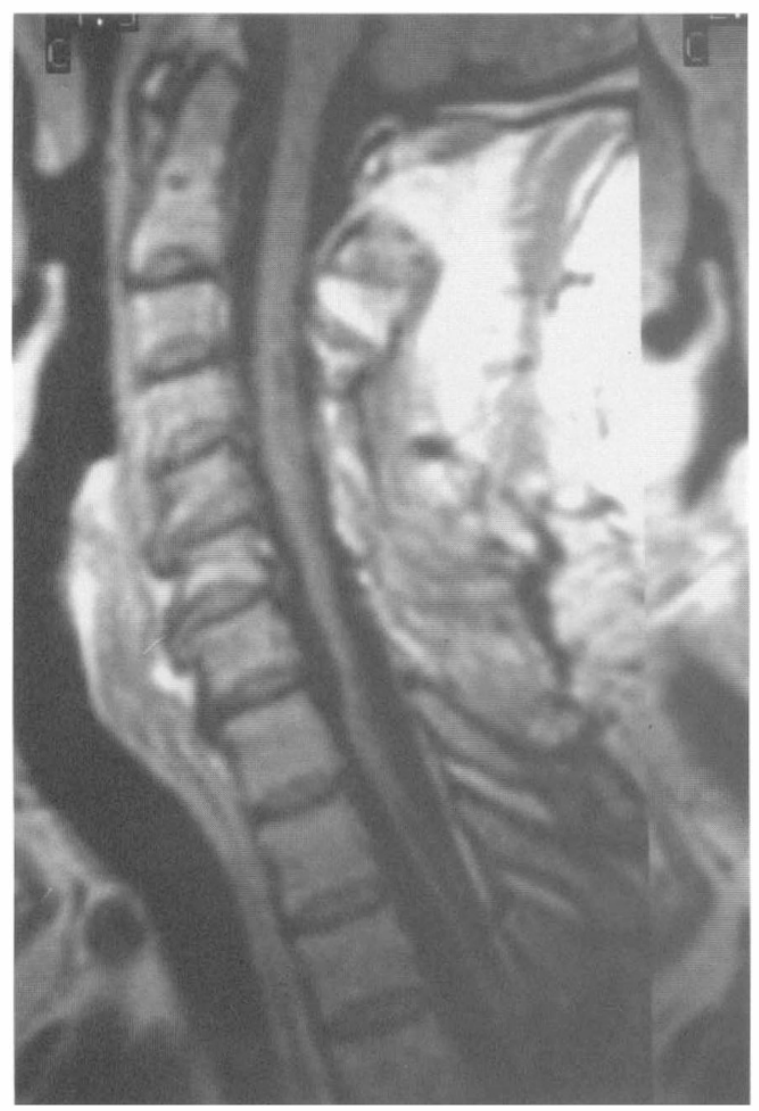

Figure 8 Multiple centrally located and longitudinally aligned malacic foci above a collapsed syrinx final proof of the pathology must depend upon surgical findings and necropsy examination. This is impossible in a large series of cases for obvious reasons. Itaru Ohshio et $a l^{26}$ reported correlations between histopathological features and magnetic resonance images in a series of 19 formalin fixed spinal cords. Among them 7 were injured spinal cords. In their study only transverse sections were examined. Signal intensity was the only accurate parameter used to describe the lesion and general terms such as 'severe destruction' and 'gray matter indistinguishable from the white matter' were used in the paper. It is difficult to compare their results with ours which are based on sagittal sections and clear definitions of lesions.

There are few published reports of the incidence or extent of extended atrophy following spinal cord injury. ${ }^{1,4,24}$ Yamashita et at reported 5 cases in their series. In our series extended atrophy was present in $62 \%$ of patients. It should be more widely studied because it is the most commonly seen pathology that is associated with neurological change. The same applies to malacia which, though less common than atrophy, is still an important associated feature of neurological change.

Nordqvist ${ }^{21}$ reported the results of post-mortem myelographic and direct spinal cord measurements in 101 cadavers, none of which had had signs of organic neurological disease. The mean sagittal diameter of the spinal cord obtained by direct measurement of the cords in the age group $70-88$ was significantly smaller than in the age group 18-69. The difference in the mean sagittal diameter was about $1.0 \mathrm{~mm}$ for the cervical cord and $0.5 \mathrm{~mm}$ for the thoracic cord. The number (30) of patients used to determine the lower limit of sagittal diameter of normal spinal cord in our study was too small to be divided into age groups. If Nordqvist's result is taken into consideration, then 2 patients with atrophy in our series who are over 70 should be excluded from the atrophy group. This number is insignificant from a statistical point of view and so can be ignored.

Nordqvist also found that the reduction in the sagittal diameter of the spinal cord is mainly due to demyelination. The latter was seen in all spinal cords of cadavers over 70 years of age. He did not determine the cause of the demyelination. The histological findings of his study showed that all 18 cadavers of those aged 62 or over at death had changes in the intramedullary vessels while those under 62 did not. All over 62 had changes in the aorta whilst only 9 of the 13 under 62 had such changes. These vascular changes might have been the cause of the demyelination which took place a decade later. Although atherosclerotic changes were common in the aorta, they were not seen in the anterior spinal artery. Kakulas and Jellinger made similar observations. ${ }^{27,28}$

All our patients who had their cervical spines scanned showed degenerative changes. This might have suggested that these changes rather than the spinal cord injury were the cause of extended atrophy. 
However, that all 5 patients in our series with Grade C degeneration, the most severe change, had no extended atrophy suggests that these changes were unlikely to blame for the pathology.

There is no generally agreed definition of the terms cyst and syrinx in the literature. Gebarski et al ${ }^{11}$ use post-traumatic progressive myelopathy to include cyst, syrinx and malacia, the syrinx being a large cyst. Falcone $e t a l^{3}$ differentiate malacia from cyst and syrinx. They see cyst and syrinx as one group and call syrinx a confluent intramedullary cyst and the whole group progressive post-traumatic cystic myelopathy. Backe et $\mathrm{l}^{18}$ and Marshall and Garfin ${ }^{9}$ define a syrinx as any area of cord with a low signal intensity equivalent to that of CSF and regardless of its length. Greenfield ${ }^{29}$ and Williams ${ }^{30}$ reserve the term syrinx for cavities several segments in length. Sett and Crockard $^{5}$ and Silberstein and Hennessey ${ }^{6,7}$ use the terms cyst and syrinx interchangeably. Barnett $e e^{31}$ define a syrinx as a cavitation in the spinal cord tending to extend in a longitudinal direction.

Perovitch et $a l^{32}$ consider a cavity to be a syrinx only if signal changes probably related to flow phenomena can be demonstrated within it. It is uncertain whether or not the syrinx cavity communicates with the subarachnoid CSF system. The 'CSF flow' may simply reflect the thinness of the syrinx wall, and the fluid rather than the gel nature of the syrinx contents, and hence transmissibility of true CSF pulsation dynamics.

In this study cysts are strictly focal. All cysts in this series were confined to the very small area adjacent to the point of maximal bony protrusion into the canal. This suggests that they are the end result of direct impact at the time of injury. The surrounding ring with a T1 signal intensity higher than that of the cyst cavity seen in 4 of our cases suggests an inner lining or encapsulation, ${ }^{6,11}$ and hence, a focalised and stable lesion. Cysts were not associated with neurological change unless another spinal cord pathology was present as well. By contrast syrinxes, malacia and atrophy on their own were associated with changes. This further supports that a cyst is a stable lesion whilst a syrinx is potentially progressive, though not necessarily symptomatic. Cyst and syrinx are probably different clinico-pathological entities.

In contrast to cysts, all but one syrinx were in close proximity but not directly adjacent to the point of maximal bony protrusion into the spinal canal. At the point of maximal bony protrusion the cord is atrophied. Syrinxes tended to extend so are probably more than just the result of early secondary changes.

Tethering has been thought to be a possible mechanism of syrinx formation. ${ }^{10,30,33-35}$ However, it is not apparently associated with post-traumatic syrinx in our series except in one case where it is seen at the site of laminectomy and shunting. It is possible that the prevalence of tethering recorded with our machine is lower than its actual prevalence. Osborne et $a l^{36}$ reported 18 cases of tethering without seeing a case of syrinx. Ragnarsson et $a l^{37}$ reported a case of suspected syrinx where operative exploration revealed tethering and cord atrophy without syrinx. It is likely that the role of tethering in the development of a posttraumatic syrinx has been over-emphasised. The hypothesis was formulated in the pre-MRI era when accurate diagnosis of spinal cord pathology was difficult.

Williams ${ }^{30,33,34}$ suggested that in association with adhesions around the spinal cord there were upward and downward surges of CSF during coughing, which led to the extension of syrinx. He also postulated that the upward surge was more energetic than the downward one. In our series the numbers of upward and of downward extension are equal. In addition, Tobimatsu et $a l^{38}$ observed in their MRI flow study that the flow in the syrinx was synchronized with the heart beat rather than breathing. The observations of our study on tethering and the direction of extension of the syrinx do not support Williams' hypothesis.

Some studies suggest that late vascular change leads to malacia, which in turn develops into a syrinx. ${ }^{1,3,31,39-43}$ Perovitch, ${ }^{41}$ using MRI spinal cord angiography, has seen thrombosis of the spinal cord vascular system in association with cystic myelopathy. Segmental ischaemia may be the precursor of myelomalacia. Two cases in our series support this view.

It seems possible that there are two mechanisms for the extension of syrinxes. These may be present alone or in combination. One is direct expansion of an existing syrinx due to pressure build-up as a result of flow of content of the syrinx or other factors. This flow phenomenon has been shown in recent MRI studies. $6,32,38,42$ The other is merging of malacic foci as has been seen in the above-mentioned case. The latter may well explain the loculation and septation between various parts of a syrinx. It may also explain the failure of shunting to reverse the symptoms in some patients where neurological damage has already been done by the malacia before the syrinx has developed.

There is no significant difference in the numbers of each pathology in different periods after injury or at different ages. This suggests that there is a stage at which the pattern of tertiary change for any individual becomes established, though its degree and extent may still change. The exception is that the prevalence of syrinxes in thoracic level patients appears to be much higher in the $30-39$ years post injury group compared with those 20-29 years post injury. This may be explained by the further development of syrinxes in the surviving thoracic patients in the $30-39$ years group. The decreased prevalence of syrinx in the cervical patients in 30-39 post injury group compared with $20-29$ post injury group may be explained by an increasing mortality in cervical patients with syrinxes.

Prior to MRI scanning the incidence of syrinxes was reported to be from $1.1-3.2 \%{ }^{31,44}$ Following the introduction of MRI scanners, Sett and Crockard 
reported it as $33.3 \%$ and Backe et $a l^{8}$ as $51 \%$. Silberstein and Hennessy ${ }^{6}$ found cystic myelopathy, which includes syrinxes, cysts and malacia, in $59 \%$ of cases. As these authors did not have a clear differentiation between cyst, syrinx and malacia and Sett and Crockard included only referred patients, it is difficult to compare their prevalence of each pathology with ours. In our series, $20.9 \%$ of patients had a syrinx, $9.1 \%$ a cyst and $55.6 \%$ malacia. When cyst, syrinx and malacia are combined together, then a total of 122 patients $(80 \%)$ had either a single pathology or a combination. This much higher prevalence than all the previous reports remains to be explained.

This study shows that patients with longer syrinxes are more likely to have symptoms though some patients with huge syrinxes remain free of neurological change. From the statistical point of view an extending asymptomatic syrinx should be considered for shunting to reduce the risk of its becoming symptomatic. In addition, once a patient becomes symptomatic there is always a risk that the symptoms will not be reversed even with flawless surgery. ${ }^{30}$ Tobimatsu et $a l^{38}$ analysed the CSF flow in the posttraumatic syrinx and found that 10 out of the 11 patients with CSF flow phenomena in the syrinx were symptomatic while 4 of the 5 without were asymptomatic. They concluded that an MRI study of CSF flow phenomena was valuable in determining the prognosis of a post-traumatic syrinx. Five of the 11 patients with only caudal extension of syrinxes in our series had neurological change which included pain and spasms but not sensori-motor alteration. Surgery in these cases should be determined by the severity of the symptoms and the patient's response to conservative treatment. Despite the guidelines mentioned above each case should be considered on an individual basis because of the risks associated with surgical intervention.

It is a common clinical experience that pain and spasms occur when the patient is recovering from acute spinal cord injury. Kakulas ${ }^{39}$ has observed that patients with severe pain survive longer and in these patients nerve root regeneration is more frequently seen than in other patients. In our study, the mean ages of patients with pain or spasms are either equal to or greater than the mean age of those without neurological change. Pain and spasms may not be signs of 'deterioration'.

Two cases in our series with relatively moderate injury at thoracolumbar level had atrophy that extended into their upper cervical cords (Figure 9). By contrast, in three other cases where there was near disruption of the cord at the lower cervical or upper thoracic level, no extended atrophy was seen (Figure 10). These findings suggest that there was a tertiary change, a process other than but related to the original injury, which gave rise to the distant extended atrophy.

It is interesting to note that patients with complete disruption of the cord had less neurological change after initial neurological stabilisation. Cordectomy has been applied with some good results as treatment for syrinxes, ${ }^{30}$ pain and spasms. ${ }^{45}$

The absence of a significant difference in the prevalence of spinal cord pathology and neurological change between patients with spinal canal compromise
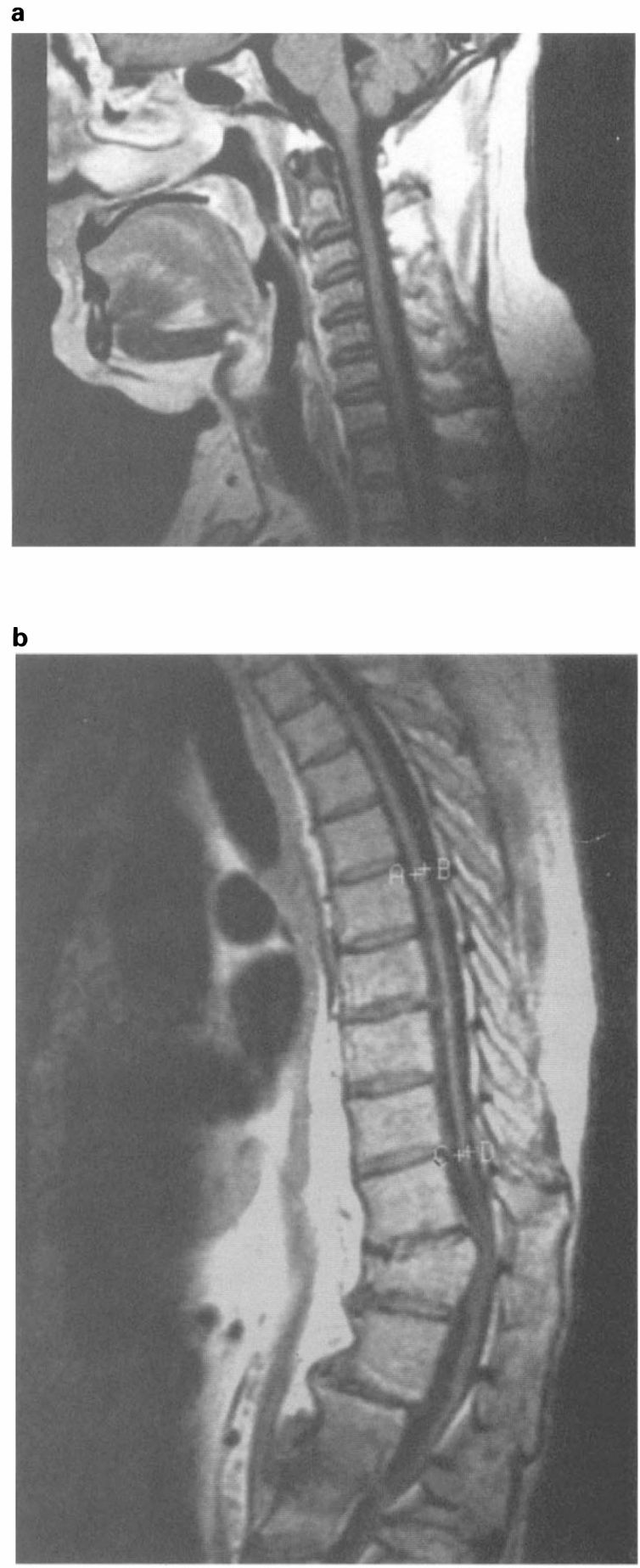

Figure 9 ( $a$ and b). Atrophy of the entire spinal cord in a patient with a fracture of the 12 th thoracic vertebra 


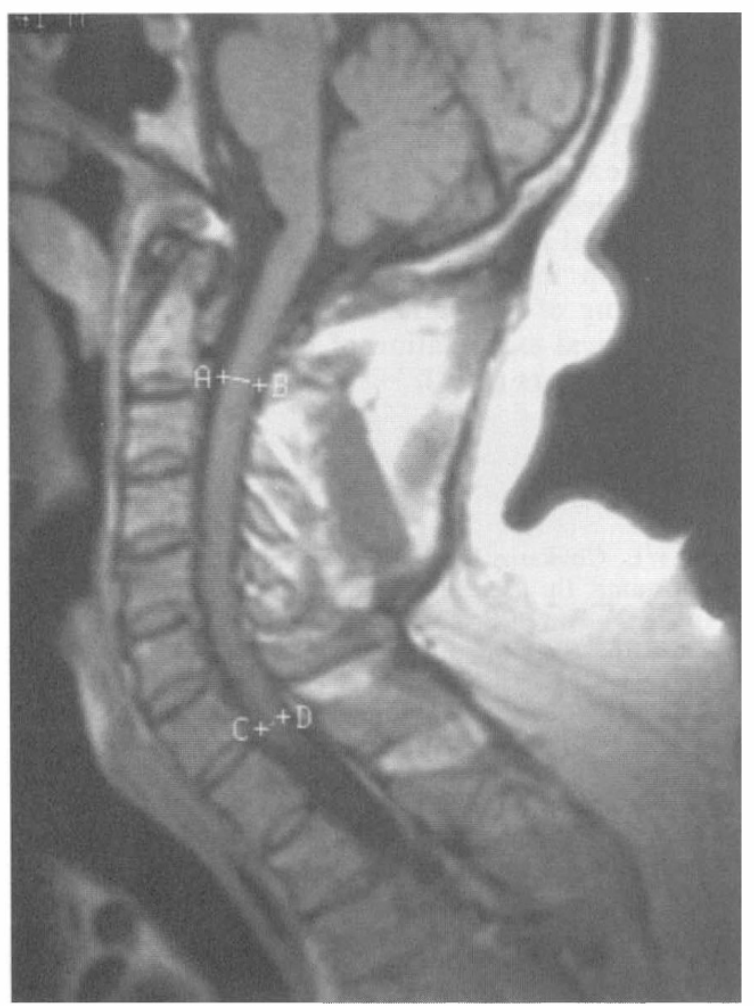

Figure 10 The cord has been transacted but there is no atrophy visible above the transaction

and those without suggests at first sight that decompression of the spinal canal will not prevent these changes from developing.

There is no correlation between the degree of angulation of the spine adjacent to the level of injury and either the prevalence of each lesion or the incidence of late neurological change. It even appears that neurological change is least commonly seen in patients with the most severe kyphosis (Tables 23-25). This apparent anomaly may be explained by the observation that cord disruption or near disruption, which is most commonly seen in severe kyphosis is associated with fewer late neurological changes than other pathologies. In any event, our results suggest that correction of kyphotic deformity is not important in preventing neurologically significant tertiary spinal cord change.

Oedema, focal and local malacia, cysts and tethering are secondary changes that are the result of direct injury to the spinal cord and its coverings. Syrinx, late and remote malacia and late extended atrophy, especially those inconsistent with the severity and site of injury, need some mechanism other than the original injury to explain them. They are tertiary changes that develop after the initial neurological stabilisation.

The secondary changes that result from the initial impact are largely not preventable. This may not be the case with the tertiary changes that arise after the stage of initial neurological stabilisation. Further research into the pathologies of these tertiary changes may give rise to treatments that will prevent their development.

It should be mentioned that our study involved patients more than 20 years after injury. Many with severe spinal cord tertiary lesions may already have died. Therefore the actual prevalence of the lesions may be higher than that of this study. Thus, the fact that the prevalence of syrinxes in cervical patients is more common in our series in the 20-29 year post injury group compared with the $30-39$ one may be because syrinx formation in cervical patients is a significant risk to life.

Apart from neuronal regeneration, developments in laboratory research have increasingly emphasised the importance of the environment in successful spinal cord regeneration. ${ }^{46}$ The prevention of conditions leading to tertiary changes will provide a more optimal environment for regeneration.

In one of our patients with a C5-6 vertebral injury the cord was less than one third of its normal diameter and malacic. The cord above and below it was atrophic (Figure 11). Surprisingly, this patient had only a minor neurological deficit, Frankel Grade D.

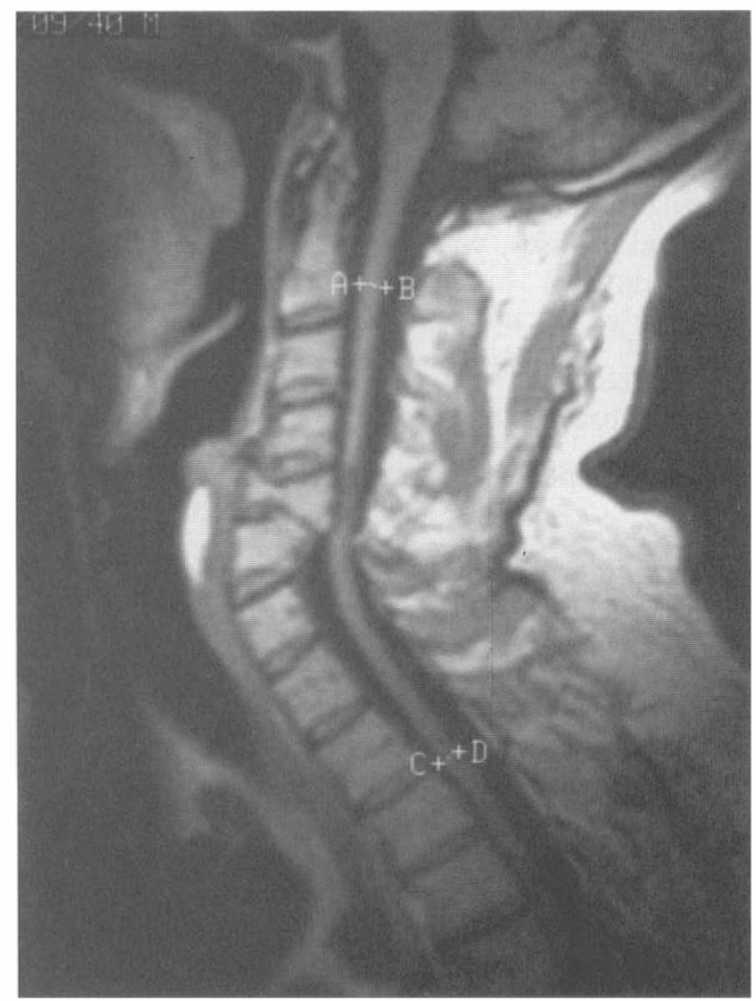

Figure 11 The cord at the level of injury is less than one third of its normal diameter and is malacic. The cord above and below the injury is atrophic. 
This observation further supports the view that only a small proportion of spinal cord is needed for its basic functioning. ${ }^{47}$

\section{Conclusions}

1 Chronic spinal cord pathologies include, in order of prevalence, extended atrophy, malacia, syrinx, cyst, cord disruption and tethering. Focal and local malacia, cyst and tethering are secondary changes whilst syrinx, late and remote malacia and late extended atrophy are tertiary changes.

2 Extended atrophy was most commonly seen in injuries of the cervical spine, malacia in those of the thoracolumbar and lumbar spine, and syrinxes in those of the thoracic spine.

3 With the exception of syrinxes there is no correlation between the prevalence of each pathology, the age of the patient at the time of the study and the length of time after injury.

4 Syrinxes were most common in the thoracic region and in the 30-39 year post injury group. This probably reflects survival patterns in which the thoracic injury group outlived the cervical but not the lumbar injury group. It also indicates that syrinxes develop further with increasing year post injury in the 30-39 year group.

5 There is no correlation between the prevalence of each pathology, the presence of neurological change, and either the degree of spinal canal compromise or the degree of angulation of the spine adjacent to the level of injury.

6 Syrinx and cyst are different pathological and clinical entities, with probably different aetiologies and natural histories. Syrinxes are progressive lesions whilst cysts are stabilised ones.

7 The longer the syrinx the greater the chance that it is symptomatic.

8 Cord disruption is not associated with neurological change.

9 Tethering was very rarely seen. It was not directly associated with syrinx formation.

10 The neurological changes after initial neurological stabilisation were, in order of prevalence, neurogenic pain, increased spasms, elevation of sensory level and decreased motor power.

11 Vascular myelopathy may be a cause of the extended atrophy and malacia that is inconsistent with the severity and site of injury. Malacia in turn may be a precursor of syrinx formation.

12 The prevention of factors leading to tertiary changes will provide a better environment for regeneration.

\section{Acknowledgements}

The authors are grateful to the International Spinal Research Trust for its support that has made the project possible. We would also like to thank Susie Charlifue from the Craig Hospital, Colorado and Dr G Savic of the National Spinal Injuries Centre, Stoke Mandeville Hospital for their help in organising the clinical assessment and MRI scanning of the patients. Dr Savic also took part in the neurological examination of the patients together with one of the authors (DW).

\section{References}

1 Olsen WL, Chakeres DW, Berry I, Richaud J. Spine and spinal cord trauma. In: Imaging of the spine and the spinal cord (editor: Manelfe C), Raven Press, New York: 1992; 407-444.

2 Quencer RM, Sheldon JJ, Donovan Post MJ, Diaz RD, Montalvo BM, Green BA, Eismont FJ. Magnetic Resonance Imaging of the chronically injured spinal cord. AJNR 1986; 7: 457-464.

3 Falcon S, Quencer RM, Green BA, Patchen SJ, Donovan Post MJ. Progressive posttraumatic myelomalacic myelopathy: imaging and clinical features. AJNR 1994; 15: 747-754.

4 Yamashita Y, Takahashi M, Matsuno Y, Sakamoto Y, Oguni T, Sakae T, Yoshizumi K, Kim Edmund. Chronic injuries of the spinal cord: assessment with MR imaging. Radiology 1990; 175: $849-854$.

5 Sett P, Crockard HA. The value of magnetic resonance imaging (MRI) in the follow-up management of spinal cord injury. Paraplegia 1991; 26: 396-410.

6 Silberstein M, Hennessy O. Cystic cord lesions and neurological deterioration in spinal cord injury: operative consideration based on magnetic resonance imaging. Paraplegia 1992; 30: 661-668.

7 Silberstein M, Hennessy O. Implications of focal spinal cord lesions following trauma: evaluation with magnetic resonance imaging. Paraplegia 1993; 31: $160-167$.

8 Backe HA, Betz RR, Mesgarzadeh M, Beck T, Clancy M. Posttraumatic spinal cord cysts evaluated by magnetic resonance imaging. Paraplegia 1991; 29: 607-612.

9 Marshall LF, Garfin S. Chapter 2, Incidence and cause of neurological deterioration following spinal cord injury. In: Piepmeier IM, editor. The outcome following traumatic spinal cord injury, Futura Publishing Company Inc. Mount Kissco, New York: 1992; 13-29.

10 Wilberger JE, Maroon JC, Whiting D. Chapter 3, Radiographic investigation of the post-spinal cord injury patient. In: Piepmeier IM, editor. The outcome following traumatic spinal cord injury, Futura Publishing Company Inc. Mount Kissco, New York: 1992; 31-55.

11 Gebarski SS, Maynard FW, Gabrielsen TO, Knake JE, Latack JT, Hoff JT. Posttraumatic progressive myelopathy. Radiology, 1985; 157: $379-385$.

12 Chackeres DW, Flickinger F, Breshahan JC, Beattie MS, Weiss KL, Miller C, Stokes BT. MR imaging of acute spinal cord trauma. AJNR 1987; 8: 5-10.

13 Hackney DB, Asato R, Joseph PM, Carvlin MJ, McGrath JT, Grossman RI, Kassab EA, DeSimone D. Haemorrhage and oedema in acute spinal cord compression: Demonstration by MR imaging. Radiology 1986; 161: $387-390$.

14 Weirich SD, Cotler HB, Narayana PA, Hazle JD, Jackson FE, Coupe KJ, McDonald CL, Langf ord LA, Harris JH. Histopathological correlation of magnetic resonance imaging signal patterns in a spinal cord injury model. Spine 1990; 15: 630-638.

15 Bonduranti F J, Cotler HB, Kulkarni, McArdle CB, Harris JH. Acute spinal cord injury: A study using physical examination and magnetic resonance imaging. Spine 1990; 15: 161-168.

16 Schaeffer DM, Flanders A, Osterholm JL, Northrup BE. Prognostic significance of magnetic resonance imaging in the acute phase of cervical spine injury. $J$ Neurosurg 1992; 76: $218-$ 223. 
17 Beers GJ, Raque GH, Wagner GG, Shields CB, Nichols GR, Johnson JR, Meyer JE. MR imaging in acute cervical spine trauma. J Comput Assist Tomogr 1988; 12: 755 - 761 .

18 Fujii H, Yone K, Salou T. Magnetic resonance imaging study of experimental acute spinal cord injury. Spine 1993; 18: $2030-$ 2034.

19 Silberstein M, Brown D, Tress BM, Hennessey O. Suggested MRI criteria for surgical decompression in acute spinal cord injury. Preliminary observations. Paraplegia 1992; 30: 704-710.

20 Whiteneck GG, Charlifue SW, Frankel HL, Fraser BM, Gardner BP, Gerhart MS, Krishnan KR, Nuseibeh I, Short DJ, Silver JR. Mortality, morbidity and psychosocial outcomes of persons spinal cord injured more than 20 years ago. Paraplegia 1992; 30: $617-630$.

21 Nordqvist L. The sagittal diameter of the spinal cord and subarachoid space in different age groups (A roentgenographic post-mortem study). Acta Radiologic Supplementum, Stokhholm, Almqvist Wiksells, Boktryckeri Aktiebolag, Uppsala. 1964.

22 Yaszemski MJ, White III AA, Panjabi MM. Chapter 1, Biomechanics of the spine. In: Vinken PJ, Bruyn GW (editors) Frankel H (co-editor). Handbook of Clinical Neurology, vol. 61, revised series 17. North-Holland Publishing Company, Amsterdam, Oxford, American Elsevier Publishing Co., Inc. New York: 1993; 3- 19.

23 Bodley R, Jamous A, Mitchell K. A two year follow-up of the MRI changes in the spinal cord of patients with acute traumatic cord lesions. Paper presented at the 31st Annual Scientific Meeting of the International Medical Society of Paraplegia. 1992.

24 Holtzman RNN, Yang. Chapter 9: Spinal cord atrophy. In: Holtzman RNN, Stein BN (editors) Surgery of the spinal cord. Potential for regeneration and recovery. 1992; 165-196.

25 Teddy P. Personal communication, 1995.

26 Ohshio I, Hatayama A, Kaneda K, Tkahara M, Nagashima K. Correlation between histopathologic features and magnetic resonance images of spinal cord lesions. Spine 1993; 18: $1140-$ 1149.

27 Jellinger K. Spinal cord arteriosclerosis and progressive vascular myelopathy. J Neurol, Neurosurg and Psychiat 1967; 30: 195206.

28 Kakulas B. Pathology of spinal injuries. Central Nervous System Trauma 1984; 1: $112-129$.

29 Greenfield JG. In: Greenfield JG, editor. Neuropathology 1958; Arnold, London, 306-312.

30 Williams B. Chapter 10, Post-traumatic syringomyelia (cystic myelopathy). In: Vinken PJ, Bruyn GW (editors) and Frankel $\mathrm{H}$ (co-editor). Handbook of Clinical Neurology, vol. 61, revised series 17. North-Holland Publishing Company, Amsterdam, Oxford, American Elsevier Publishing Co., Inc. New York: 375-398. 1993.

31 Barnett HJM, Jousse AT. Chapter 10, Post-traumatic syringomyelia (cystic myelopathy) In: Vinken PJ, Bruyn GW (editors) Handbook of Clinical Neurology. Injuries of the spine and spinal cord, Part II. North-Holland Publishing Company, Amsterdam, Oxford, American Elsevier Publishing Co., Inc. New York: 113159. 1976.
32 Perovitch M, Wang H, Perl S. Magnetic resonance imaging of traumatic syringomyelia. International Congress on Paraplegia, Gent, Belgium. 18. 1993.

33 Williams B, Terry AF. Syringomyelia as a sequel to traumatic paraplegia. Paraplegia 1981; 19: 67-80.

34 Williams B. Post-traumatic syringomyelia, an update. Paraplegia 1990; 28: $296-313$.

35 Caplan LR, Norohna AB, Amico LL. Syringomyelia and arachnoiditis. J Neurol, Neurosurg and Psychiat 1990; 53: $106-$ 113.

36 Osborne DRS, Vavoulis G, Nashold BS, Drayer BP, Heinz. Late sequelae of spinal cord trauma (myelographic and surgical correlation). J Neurosurg 1982; 57: 16-32.

37 Ragnarsson TS, Durward QJ, Nordgren RE. Spinal cord tethering after traumatic paraplegia with late neurological deterioration. J Neurosurg 1986; 64: $397-401$.

38 Tobimatsu R, Nihei R, Kimura T, Suyama T, Kimura H, Tobimatsu H, Shirakawa T. A quantitative analysis of CSF flow of posttraumatic syringomyelia. International Congress on Paraplegia, Gent, Belgium. 19. 1993.

39 Kakulas BA, Taylor JR. Chapter 2, Pathology of injuries of the vertebral column and spinal cord. In: Vinken PJ, Bruyn GW (editors), Frankel H (co-editor). Handbook of Clinical Neurology, vol. 61, revised series 17. North-Holland Publishing Company, Amsterdam, Oxford, American Elsevier Publishing Co., Inc. New York: $21-51.1993$.

40 Mair WGP, Drunckman R. The pathology of spinal cord lesions and their relation to the clinical features in protrusion of cervical intervertebral discs. Brain 1953; 76: 70 - 91 .

41 Perovitch M. Personal communication, 1994.

42 Quencer RM. The injured spinal cord. Evaluation with magnetic resonance and intraoperative sonography. Rad Clin North Am 1988; 26: 1025 - 1045 .

43 Enzmann DR, DeLaPaz RL. Chapter 6, Trauma. In: Enzmann DR, DeLaPaz RL (editors) Magnetic resonance of the spine. The CV Mosby Company, St Louis, Baltimore, Philadelphia, Toronto: 1990; 237-259.

44 Rossier AB, Foo D, Shillito J, Dyro FM. Post traumatic cervical syringomyelia. Incidence, clinical presentation, electrophysiological studies, syrinx protein, and results of conservative and operative treatment. Brain 1985; 108: 439-461.

45 Sweet WH, Poletti CE, Gybels J M Chapter 59, Operations in the brain stem and spinal canal, with an appendix on the relationship of open to percutaneous cordotomy. In: Wall PD, Melzack R (edit) Textbook of pain. Churchill Livingstone, Edinburgh, London, Madrid, Melbourne, New York, Tokyo: 1994; 1113 1136.

46 Raisman G. Lecture of the International Spinal Research Trust. 1994.

47 Young W. Chapter 23, Clinical trials and experimental therapies of spinal cord injury. In: Vinken PJ, Bruyn GW (editors) and Frankel H (coeditor). Handbook of Clinical Neurology, vol. 61, revised series 17. NorthHolland Publishing Company, Amsterdam, Oxford, American Elsevier Publishing Co., Inc. New York: $1993 ; 399-421$. 